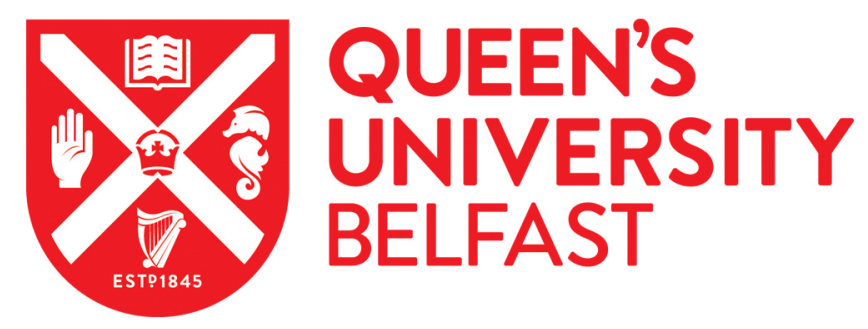

\title{
Nesseltalgraben, a new reference section of the last glacial period in southern Germany
}

Mayr, C., Brandlmeier, B., Diersche, V., Stojakowits, P., Kirscher, U., Matzke-Karasz, R., Bachtadse, V., Eigler, M., Haas, U., Lempe, B., Reimer, P. J., \& Spötl, C. (2017). Nesseltalgraben, a new reference section of the last glacial period in southern Germany. Journal of Paleolimnology, 58(2), 213-229. https://doi.org/10.1007/s10933017-9972-0

Published in:

Journal of Paleolimnology

Document Version:

Peer reviewed version

Queen's University Belfast - Research Portal:

Link to publication record in Queen's University Belfast Research Portal

Publisher rights

Copyright 2017 Springer Verlag. This work is made available online in accordance with the publisher's policies. Please refer to any applicable terms of use of the publisher.

\section{General rights}

Copyright for the publications made accessible via the Queen's University Belfast Research Portal is retained by the author(s) and / or other copyright owners and it is a condition of accessing these publications that users recognise and abide by the legal requirements associated with these rights.

Take down policy

The Research Portal is Queen's institutional repository that provides access to Queen's research output. Every effort has been made to ensure that content in the Research Portal does not infringe any person's rights, or applicable UK laws. If you discover content in the Research Portal that you believe breaches copyright or violates any law, please contact openaccess@qub.ac.uk. 
1 Nesseltalgraben, a new reference section of the Last Glacial period in southern Germany

2

3 Christoph Mayr $^{1,2,3}$, Birgit Brandlmeier ${ }^{2}$, Volker Diersche ${ }^{4}$, Philipp Stojakowits ${ }^{5}$, Uwe

4 Kirscher $^{6,7}$, Renate Matzke-Karasz ${ }^{2,3}$, Valerian Bachtadse ${ }^{7}$, Michael Eigler $^{2}$, Ulrich Haas ${ }^{8}$,

$5 \quad$ Bernhard Lempe ${ }^{9}$, Paula J. Reimer ${ }^{10}$, Christoph Spötl $^{11}$

6

$7{ }^{1}$ Institut für Geographie, Friedrich-Alexander-Universität Erlangen-Nürnberg, Wetterkreuz

$8 \quad 15,91058$ Erlangen, Germany

$9{ }^{2}$ Department für Geo- \& Umweltwissenschaften, Paläontologie \& Geobiologie, Ludwig-

10 Maximilians-Universität München, Richard-Wagner-Str. 10, 80333 Munich, Germany

$11{ }^{3}$ GeoBio-Center, Ludwig-Maximilians-Universität München, Richard-Wagner-Str. 10, 80333

12 Munich, Germany

$13{ }^{4}$ Schiller-Allee 1, 83457 Bayerisch Gmain, Germany

145 Institut für Geographie, Universität Augsburg, Alter Postweg 118, 86135 Augsburg, 15 Germany

$16{ }^{6}$ Earth Dynamics Research Group, ARC Centre of Excellence for Core to Crust Fluid Sys17 tems (CCFS) and The Institute for Geoscience Research (TIGeR), Department of Applied 18 Geology, Curtin University, GPO Box U1987, WA 6845, Australia

20 Universität München, Theresienstr. 41, 80333 Munich, Germany

218 Bayerisches Landesamt für Umwelt, Bürgermeister-Ulrich-Str. 160, 86179 Augsburg, 22 Germany

$23{ }^{9}$ Lehrstuhl für Ingenieurgeologie, Technische Universität München, Arcisstraße 21, 80333

24 München, Germany

$25{ }^{10}$ Centre for Climate, the Environment \& Chronology (14CHRONO), School of Natural and 26 Built Environment, Queen's University Belfast, Belfast BT7 1NN, UK 
${ }^{11}$ Institut für Geologie, Leopold-Franzens Universität Innsbruck, Innrain 52, 6020 Innsbruck, 28 Austria

Key words: lake sediments, Berchtesgaden, Würmian, geochemistry, carbon isotopes, pollen, magnetostratigraphy, Northern Calcareous Alps

\section{Abstract}

In the northern Alpine region only a few lacustrine sediment sequences are known from the period of the Last Glacial, regionally assigned as Würmian. Even less is known about Alpine palaeoenvironments prior to the Last Glacial Maximum (LGM). The recently discovered sediment sections at the Nesseltalgraben site (northern Alps, southern Germany) presented here, comprise an approximately $27 \mathrm{~m}$ high, predominantly lacustrine composite profile below coarse clastic sediments assigned to the LGM and underlain by Permian-Triassic evaporitic and sandy clayey sediments of the Haselgebirge and Werfen-Formation. The Würmian lake sediments consist of carbonate mud layers representing cooler phases, and organic rich layers (compressed peat, organic mud), that were deposited during warmer periods. Bulk organic geochemical analyses suggest that predominantly algal organic matter was deposited during the cooler periods, while higher fractions of terrestrial vascular plants were admixed during warmer phases. A diamict represents an erosional unconformity and cuts the sediment sequence into a lower and an upper part. Paleomagnetic, palynostratigraphic and radiocarbon analyses place the lower part into the Marine Isotope Stage (MIS) 5c (Lower Würmian), while the upper part covers at least the period from 45 to $31 \mathrm{ka}$ cal BP (MIS 3, Middle Würmian). Different explanations for the origin and spatiotemporal extent of the palaeolake are discussed. The most plausible sedimentary deposition is the formation of the small-scaled lake in a sinkhole in the evaporitic Haselgebirge Formation. The results highlight 
the significance of the Nesseltalgraben site as a new reference section of the Last Glacial

54 period in the Northern Calcareous Alps and call for the necessity of further geochronological 55 and paleoenvironmental studies at that site.

Stable isotope records from Greenland ice cores revealed that the last glacial period, referred to as the Weichselian in northern Europe and the Würmian in the Alpine realm, was characterized by a general trend toward lower air temperatures interrupted by centennial- to millennial-scale interstadials. Twenty-five of these Greenland interstadials or so-called Dansgaard-Oeschger (D-O) events were identified, interrupted by 26 Greenland stadials (Rasmussen et al. 2014). Some of the stadials are associated with Heinrich events, massive discharges of icebergs into the North Atlantic, mainly derived from the Laurentide ice sheet (Seierstad et al. 2014). Evidence for climate changes associated with D-O and/or Heinrich events have been found in European climate archives, including loess deposits (Antoine et al. 2009), speleothems (Genty et al. 2003), and lacustrine sediments (Sirocko et al. 2005; Wohlfarth et al. 2008; Pini et al. 2010).

The impact of these climatic events during the last Glacial on Alpine ecosystems, however, is poorly known. This is partially due to a lack of adequate records in the northern Alps and their foreland, which is the classic area where the Würmian was originally defined (Penck 1882). The few records available include speleothems, peat and lake sediments. Alpine speleothems cover time spans from 120 to 35 kiloyears before present (ka BP), but do not have a continuous growth history (Boch et al. 2011; Moseley et al. 2014). Despite a long tradition of regional Quaternary research, only a few lacustrine records of Middle to Lower Würmian age have been studied in Alpine sites in Switzerland, Austria and Germany (Heiri et al. 2014; Fig. 1). This scarcity of archives reflects the pervasive erosion during the subsequent 
Last Glacial Maximum (LGM, Upper Würmian) ice advance. In particular, the Middle

80 Würmian, i.e. the period between 74 and $30 \mathrm{ka} \mathrm{BP}$, is the least explored interval of the last 81 glacial period in the Alpine realm (Preusser 2004; Heiri et al. 2014).

In the last few years, new outcrops of lacustrine and fluvial sediments have been exposed by erosion in the Nesseltalgraben close to Berchtesgaden, southeastern Germany. This site is located within the northern edge of the Alps and can contribute substantially to a better understanding of the impact of rapid climate change on Alpine ecosystems during the Würmian. The aim of this study is to document the lithology and stratigraphy of the sections exposed in the Nesseltalgraben, and to interpret the first stable isotopic and geochemical investigations on bulk organic matter. Furthermore radiocarbon, pollen, and paleomagnetic analyses were carried out to provide a chronological framework. Based on these results, first conclusions about the paleoenvironment and the origin, spatial extent and persistence of lacustrine conditions during the Würmian can be drawn.

Site description

The inner-Alpine Nesseltalgraben site $\left(47^{\circ} 39^{\prime} 24^{\prime}{ }^{\prime} \mathrm{N}, 1^{\circ} 02^{\prime} 49^{\prime}\right.$ 'E, 555-595 m a.s.l.) is located in the Northern Calcareous Alps $4 \mathrm{~km}$ northeast of Berchtesgaden and $15 \mathrm{~km}$ south of Salzburg. Geomorphologically, the Nesseltalgraben site is located in a small tributary valley at the eastern slope of the roughly S-N oriented Berchtesgaden main valley which was incised by fluvial and glacial erosion during the Quaternary. The recently discovered Pleistocene strata there are overlying bedrocks of the Upper Permian to Lower Triassic evaporitic Alpine Haselgebirge Formation (Fm.) (Spötl 1989). These rocks crop out immediately west of the Quaternary section and consist of a tectonic mélange of claystone, gypsum, anhydrite and salt, overlain by, and mixed with, up to km-sized blocks of pelagic limestones and dolomites of the Triassic Hallstatt Fm. (Fig. 2). The evaporites of the Haselgebirge Fm. are affected by 
105 subrosion leading to the formation of sinkholes (Bayerisches Landesamt für Umwelt 2013).

To the north, the Nesseltalgraben Quaternary outcrop is bordered by limestones of the Hallstatt Fm., while Triassic dolomites and the sandy to carbonate-clastic Werfen Fm. crop out in the west (Fig. 2).

\section{Material and Methods}

\section{Sedimentology}

114 Sediment exposures in the Nesseltalgraben were cleared from vegetation and soil cover and 115 were thoroughly documented. Five sections, named A to E from east to west, were sampled 116 for sedimentological and geochemical analyses. The sections were correlated using 117 lithological marker horizons. Lithology and grain size were recorded using standardized field 118 methods (Sponagel et al. 2005). Macrofossils and sedimentary structures were documented, 19 and the sedimentary units were measured with a tape measure. Subsequently, sediment blocks 120 of $10 \mathrm{~cm}$ height and approximately $500 \mathrm{~cm}^{3}$ volume, were taken continuously from the sections.

Geochemistry and stable isotopes

125 For bulk geochemical and isotopic analyses 200 samples containing sufficient fine-grained sediment were selected. A representative fraction of each sample was frozen after soaking with a small amount of de-ionized water, lyophilized (LYOVAC GT2-E freeze dryer, SRK) 128 and thereafter homogenized either carefully with a mortar or sieved $(<250 \mu \mathrm{m})$ to remove 129 coarse minerogenic and organic debris. The fine fraction was used to analyse total nitrogen 130 (TN), total carbon and total organic carbon contents (TC, TOC, in weight \%), and stable 
isotope ratios of organic carbon $\left(\delta^{13} \mathrm{C}_{\mathrm{TOC}}\right)$. Total inorganic carbon content was calculated from the difference between TC and TOC. For TN and TC analyses on average $29 \mathrm{mg}$ (maximum $110 \mathrm{mg}$, minimum $10 \mathrm{mg}$, depending on the $\mathrm{N}$ content) of the homogenized sediment were weighed into tin capsules and combusted at $1080^{\circ} \mathrm{C}$ in a continuous helium flow in an elemental analyser (NC 2500, Carlo Erba) under presence of chromium oxide and silvered cobaltous oxide. After reduction of the combustion products in a copper-filled reduction tube at $560^{\circ} \mathrm{C}$ and separation of $\mathrm{N}_{2}$ and $\mathrm{CO}_{2}$ in a gas chromatographic column at $60^{\circ} \mathrm{C}$, both gases were analysed with an isotope-ratio mass spectrometer (DeltaPlus, ThermoFisher). For TOC and $\delta^{13} \mathrm{C}_{\mathrm{TOC}}$ determination, the same method was applied, except that, before analyses, on average $11 \mathrm{mg}$ (maximum $40 \mathrm{mg}$, minimum $2 \mathrm{mg}$ ) of each sample was weighed into silver capsules and decalcified with droplets of first 5\% and subsequently $20 \%$ of $\mathrm{HCl}$ on a hot plate $\left(70^{\circ} \mathrm{C}\right)$ until no effervescence was observed. The lower concentrated $\mathrm{HCl}$ was used first to avoid excessive reaction and, thus, partial loss of the sample. Total inorganic carbon (TIC) was calculated from the difference between TC and TOC and represents a measure of carbonate content.

Carbon stable isotope values of organic matter are reported as $\delta^{13} \mathrm{C}_{\mathrm{TOC}}=$ $147\left(R_{\text {sample }} / R_{\text {standard }}-1\right) \times 10^{3}$ where $R$ is the isotope ratio $\left({ }^{13} \mathrm{C} /{ }^{12} \mathrm{C}\right) . \delta^{13} \mathrm{C}_{\text {TOC }}$ values are reported 148 relative to the Vienna Pee Dee Belemnite (VPDB) standard. Isotope values were calibrated 149 using a lab standard ('peptone-II', $\delta^{13} \mathrm{C}=-24.04 \%$ ), which is regularly calibrated against international standards (IAEA-CH7 and USGS-41). Carbon and nitrogen contents were determined from the ratio of the peak area to sample weight by using the elemental standards atropine and cyclohexanone-2,4-dinitrophenylhydrazone for calibration. The precision was 153 typically $0.1 \%$ for the isotope analyses, and $5-10 \%$ of the determined value for the nitrogen 154 and carbon content.

156 Radiocarbon dating 
Ten wood remains were dated in two radiocarbon laboratories: two samples were analyzed at the former acceleration mass spectrometry (AMS) laboratory in Erlangen and eight samples were analysed at the ${ }^{14} \mathrm{CHRONO}$ Centre, Queen's University Belfast, using AMS. The wood was pretreated following the standard acid-alkali-acid procedure (de Vries and Barendsen 1952). The sample AMS ${ }^{14} \mathrm{C} /{ }^{12} \mathrm{C}$ ratio was background corrected and normalised to the HOXII standard (SRM 4990C; National Institute of Standards and Technology). The ${ }^{14} \mathrm{C} /{ }^{12} \mathrm{C}$ ratio was corrected for isotopic fractionation using the concurrently measured ${ }^{13} \mathrm{C} /{ }^{12} \mathrm{C}$ ratio which accounts for both natural and analytical isotope fractionation. Ages were calculated according to Stuiver and Polach (1977) and were calibrated using the IntCal13 (Reimer et al. 2013) calibration curve and the Calib 7.1 software. Calibrated ages are reported with two standard deviations $(2 \sigma)$.

Palaeomagnetic analyses

Twenty-five oriented samples, one inch in diameter and up to $5 \mathrm{~cm}$ in length, were taken with a portable electrical drill from two intervals. These samples are intended to provide sister specimens were subjected to alternating field (AF) demagnetization with peak fields of $90 \mathrm{mT}$ using the automated system at the University of Munich (Wack and Gilder 2012) or analyzed using stepwise thermal demagnetization up to $600^{\circ} \mathrm{C}$ using a Schonstedt thermal 180 demagnetizer at the laboratory of the LMU. Magnetizations were measured in three 181 components after each demagnetization step with a 2-G SQUID magnetometer. 182 Demagnetization results were analyzed with principal component analysis (PCA) of at least 
183 four consecutive demagnetization steps (Kirschvink 1980). To identify eventual excursions of

the geomagnetic field, the latitude of the virtual geomagnetic pole (VGP) was calculated based on the respective directions and plotted versus stratigraphic height.

Palynology

Sediment subsamples each containing $1 \mathrm{~cm}^{3}$ were sampled above and below a diamictic layer for biostratigraphic purposes. The samples were prepared for pollen analysis following standard methods (Faegri and Iversen 1989). Lycopodium spores were added to each sample in order to determine pollen concentration (Stockmarr 1971). Pollen grains were identified under 400x and 1000x magnification using the reference collection at the Institute of Geography in Augsburg, Germany, and the pollen key of Beug (2004). Below the diamict, pollen percentages were calculated from a sum of at least 600 arboreal pollen grains. Above this layer, 500 terrestrial pollen grains were counted. For calculation of the pollen percentages, Cyperaceae, aquatics and all spores were excluded. Pollen nomenclature follows Beug (2004), spores are named according to Reille (1998).

\section{Results}

Sedimentary facies

The stratigraphy of the five sections exposed in the Nesseltalgraben is presented in Fig. 3. The sections, labeled A to E from east to west, are between 19 and 35 m apart. Marker layers, such as characteristic carbonate mud layers and a diamictic layer allow correlating individual sections despite lithological variability. For instance, about $4 \mathrm{~m}$ of predominantly coarsegrained fluvial deposits are exposed at the base of the westernmost section E, while in 
adjacent section D silt and clay are dominant at the same stratigraphic level. In both sections

plant and wood remains were found in the basal layers. The previously mentioned diamict occurs above these basal layers. It can be traced as an erosional unconformity between sections $\mathrm{C}$ and $\mathrm{E}$. While the diamict is not exposed in section $\mathrm{B}$, it occurs in the easternmost section A directly underneath a thick lacustrine carbonate mud layer, which can be traced as a marker horizon through sections $\mathrm{A}, \mathrm{B}$, and $\mathrm{C}$ (Fig. 3). In section $\mathrm{A}$ the diamict appears in a stratigraphic position several meters higher than in section $\mathrm{C}$ (Fig. 3). A much weaker inclination of the diamict layer towards the west continues in sections D and E. In section A a dark-gray organic-rich silt is sandwiched in between the diamict. In the uppermost $0.6 \mathrm{~m}$ of the lacustrine silts below the diamict of section A, mammoth bone fragments were found and the diamict itself contained a bovid metacarpale. The diamict layer consists of poorly rounded to angular, unsorted gravel, cobble, and boulders up to several decimeters in size in a siltysandy matrix. The coarse fraction consists of Triassic Hallstatt limestone and rarely Lower Cretaceous sandstones from the Roßfeld Fm., which crop out nearby. At the top of the diamict subangular to subrounded boulders of up to $1 \mathrm{~m}$ in diameter occur in section $\mathrm{C}$. In section $\mathrm{B}$ the diamict is overlain by grayish silts and clays rich in organic remains intercalated by decimeter- to meter-thick, whitish layers of homogeneous to layered carbonate muds onlapping on the diamict. The total stratigraphic height of this succession of pale white to dark gray layers compiled in a composite profile (Fig. 4) is about $13 \mathrm{~m}$. In the lower part, stems of charophytes are abundant in carbonate-rich layers at 22.3 to $22.5 \mathrm{~m}$ of the composite profile. This succession ends with a $50 \mathrm{~cm}$ thick dark-brown compressed peat layer containing abundant moss and some wood fragments in section B. This layer represents the onset of a gradual facies change, which is evident not only in the repeated occurrence of further dm- to cm-thick dark-brown peaty or organic-rich layers, but also in the increasing abundance of 233 sand and gravel layers towards the top of the succession. In total, nine organic-rich layers are 234 present in the upper half of section B which show successively decreasing thickness towards 
the top of the sections. A variety of sedimentary structures are present, including lamination, ripples, deformed and slumped strata, wedge structures and erosional channels indicating rapidly changing depositional and post-depositional conditions (Fig. 3).

Geochemistry and stable isotope records

Geochemical and stable isotope data from the three sections B, C, and D are shown next to the composite profile in Fig. 4. TN contents range between $0.01 \%$ and $0.93 \%$ (mean $0.10 \%, \mathrm{n}$ $=200$ ) and TOC between $0.1 \%$ and $14.8 \%$ (mean $1.7 \%, \mathrm{n}=161$ ). The highest TOC and TN contents coincide with organic-rich or peaty layers in the upper half of the composite profile, the lowest with the carbonate-rich muds. TOC and TN values are highly significantly correlated $(\mathrm{r}=0.99$, Fig. 5). The intercept of the correlation close to zero indicates that inorganic $\mathrm{N}$ does not play an important role and $\mathrm{TN}$ represents predominantly organic $\mathrm{N}$. TOC/TN ratios vary between 21.0 and 5.6 (mean 13.0, $\mathrm{n}=134$ ) and TIC contents between 11.9 and $0.6 \%$ (mean $4.5, \mathrm{n}=134)$. The $\delta^{13} \mathrm{C}_{\mathrm{TOC}}$ values vary from -24.9 to $-30.4 \%$ (mean $27.6 \%, \mathrm{n}=148$ ) and are highly significantly, linearly correlated with the logarithmized TOC and $\mathrm{TN}$ values and, albeit less significantly, with the TOC/TN ratio (Fig. 5). $\delta^{13} \mathrm{C}_{\mathrm{TOC}}$ values vary only little in the lower part of the composite profile and show increasing scatter in the upper part concomitant with a higher lithological variability (Fig. 4).

Radiocarbon dates

The ten radiocarbon dates obtained from the Nesseltagraben sections comprise an age range from $>51.5$ to $27.1{ }^{14} \mathrm{C}$ ka BP (Table 1). The succession of ages is in stratigraphic order in the upper part of the exposed sections above the diamict (Fig. 3) with the exception of NE-5 and NE-2 which overlap in their calibrated age ranges (Table 1), although they were taken at 
stratigraphic levels several meters apart. The layers below the diamict vary considerably in age. The strata $1.5 \mathrm{~m}$ below the diamict in section $\mathrm{C}$ were older than $51.5{ }^{14} \mathrm{C} \mathrm{ka} \mathrm{BP}$. In contrast, ages from even lower stratigraphic levels in section E yielded ages of 38.1 and 35.2 ${ }^{14} \mathrm{C}$ ka BP (41.4-43.2 and 38.4-41.2 cal ka BP, respectively; Fig. 3), pointing towards contamination with modern carbon for these samples. An age of $43.5{ }^{14} \mathrm{C}$ ka BP $(>50.0$ to 44.2 cal ka BP) from immediately below the diamict in section A may also point to a bias in the age determinations in section E.

Pollen record

Pollen analyses were carried out at 23.2 to $26.0 \mathrm{~m}$ composite depth. This segment was chosen, as it covers the strata immediately above and below the diamictic layer and allows to biostratigraphically pinpoint the event layer and a potential hiatus associated with it. The pollen record can be separated into two local pollen zones (LPZ), one below (LPZ 1), the other (LPZ 2) above the diamictic layer. LPZ 1 (Fig. 6) is characterized by a co-dominance of Picea and Pinus. Furthermore Abies, Corylus, Betula and Alnus reach noteworthy percentages. Besides these, pollen grains of other thermophile taxa (Ulmus, Tilia, Carpinus, Acer, and Fraxinus) were found. Species growing under cooler climatic conditions are present in low values such as Larix, Pinus cembra L., Alnus viridis (Ehrh.) K. Koch and Salix. The non-arboreal pollen (NAP) spectrum reaches about $10 \%$ and is dominated by Poaceae, Cyperaceae and Cichorioideae. The pollen concentration reaches values between 18,000 and 62,000 grains $\mathrm{cm}^{-3}$.

The pollen spectrum of LPZ 2 is dominated by Pinus and Cichorioideae. The next frequent tree taxa are Picea and Betula accompanied by Pinus cembra and Alnus. The high values of Cichorioideae are likely caused by selective decomposition. The pollen preservation was worse in LPZ 2 compared to LPZ 1. Partly decomposed and damaged pollen grains 
occurred in LPZ 2. Apart from Cichorioideae the NAP consists mainly of Poaceae and

Cyperaceae together with heliophile taxa such as Artemisia, Helianthemum and Thalictrum as well as many other taxa not shown in the pollen diagram (e.g. Apiaceae, Matricaria-type, Senecio-type). The pollen concentrations are rather low (6,000 to 10,000 grains $\left.\mathrm{cm}^{-3}\right)$.

Palaeomagnetic record

Two segments were selected, the first from 12.2 to $15.1 \mathrm{~m}$ composite depth in section $\mathrm{B}$, and the second between 21.1 and $24.7 \mathrm{~m}$ in section D (Fig. 3). Generally, all demagnetization experiments yielded stable behaviour. The upper interval, however, showed consistently lower magnetic intensities (intensity of the natural remanent magnetization, NRM) associated with an increase in noise of the demagnetization data (increase of mean angular deviations, MAD, of the PCA-fit). AF demagnetization yielded one component of magnetization up to 50 mT, above which a gyroremanent magnetization (GRM) (Stephenson and Snowball 2001) dominated the directional spectrum (Fig. 7d). GRM can be taken as diagnostic for the presence of the ironsulfide greigite (Roberts et al. 2011). Two components of magnetization, however, could be separated during stepwise thermal demagnetization. A first low temperature (LT) component between 100 and $\sim 400^{\circ} \mathrm{C}$ and a less well defined high temperature (HT) component between 400 and $600^{\circ} \mathrm{C}$ (Fig. 7e). The combined results of the thermal and AF demagnetization experiments point towards greigite as the predominant carrier of magnetization together with various amounts of magnetite in the samples. A more detailed rock magnetic study would be necessary to support this preliminary interpretation. Combining the resulting directions of the AF experiments and the low temperature phase yielded a mean direction of $\mathrm{D}=358.4^{\circ}, \mathrm{I}=64.8^{\circ}, \alpha_{95}=7.6^{\circ}$ for the 30 samples studied (Fig. 311 7i), whereas the HT component showed a random distribution of directions with positive and negative inclinations (Fig. 7i). These two observations led us to believe that the LT is 
representing the primary depositional magnetic component, which can be used for further magnetostratigraphic analysis. Plotting the calculated VGP latitude versus stratigraphic height yielded a zone around $14 \mathrm{~m}$ composite depth in which several low VGP latitude values were observed (Fig. 7a). The magnetic intensity (intensity of NRM) was not lower within this interval compared with the surrounding samples (Fig. 7a).

\section{Discussion}

Age range of the section

Radiocarbon dates provide a chronostratigraphic framework for the Nesseltalgraben site. These dates, however, require critical evaluation, as some of them are at, or close to, the ${ }^{14} \mathrm{C}$ limit. Some authors suggest that ages above 35 (Briant and Bateman 2009), or even above 25 ${ }^{14} \mathrm{C}$ ka BP (Lai et al. 2014), should be viewed with caution, as already small amounts of modern carbon without more rigorous pretreatments of the samples can alter the radiocarbon dates substantially. Age reversals in the lower part of the profile illustrate that modern $\mathrm{C}$ contamination is also likely at the Nesseltalgraben. In particular, the two radiocarbon ages from the deepest sediments of the record at the base of section E are too young compared to the radiocarbon dates of overlying strata. These age reversals preclude dating the diamict and a potential hiatus associated with it, but suggest that they are likely older than some $50 \mathrm{ka}$. The palynological record permits to further clarify the stratigraphy of the lower part. The floristic differences between the two pollen zones identified below (LPZ 1) and above (LPZ 2) the diamict indicate a considerable hiatus between them. LPZ 1 represents a conifer forest 336 formed primarily by Picea and Pinus, but also thermophile deciduous taxa like Corylus and 337 Tilia occurred. A comparison with pollen records from Southern Germany and Austria, 338 including Pfefferbichl (Filzer 1967), Samerberg (Grüger 1979a, b), Wurzacher Becken 
(Grüger and Schreiner 1993), Mondsee (Drescher-Schneider 2000), Füramoos (Müller et al. 2003), Kitzbühel (Reitner and Draxler 2004; Heinisch et al. 2015), Hopfgarten (Reitner and Draxler 2004) and Unterangerberg (Starnberger et al. 2013) assigns this pollen zone to the first Early Würmian Interstadial (Brørup, MIS 5c) indicated by continuous findings of Abies with values varying between 1 and $3 \%$. In the second Early Würmian interstadial (Odderade, MIS 5a), Abies is either completely missing (e.g. at Samerberg) or restricted to single findings (e.g. at Wurzacher Becken and Füramoos). Hopfgarten, an inner-alpine site, is an exception in that respect with findings of Abies in the low percentage range.

LPZ 2 also indicates interstadial conditions, but the degree of forest cover was lower than in LPZ 1. The interpretation of the pollen data is not as clear as for LPZ 1. This is also due to the high amounts of Cichorioideae, which have a distortive effect on the pollen concentrations due to their higher resistance to decomposition compared to other pollen taxa. The open forests of LPZ 2 were composed of Pinus sp., Picea and Betula. Larix and Pinus cembra also occurred, which likely grew at higher sites according to the present-day altitudinal vegetation zonation. Most probably, a Middle Würmian Interstadial after the Dürnten interstadial (Welten 1981) is reflected by LPZ 2. Similar pollen spectra were reported from Breinetsried (Peschke 1983), which were dated around 40 years ago by Grootes (1977) to 45.5 and $48.3{ }^{14} \mathrm{C}$ ka BP for the top and bottom, respectively, of a compressed peat layer. These ages are slightly older than the age of $42.2{ }^{14} \mathrm{C}$ ka BP (47.6-43.5 cal ka BP) obtained for the top of the diamict at the Nesseltalgraben site that forms the base of LPZ 2. The Neusillersdorf record contains a peat layer which covers an age between 55 and $45 \mathrm{ka}$ BP based on luminescence dating (Fiebig et al. 2014). There, Picea played a more important role in the forest composition.

The magnetostratigraphic results can be used to further refine the age model above the 363 diamict. During the period of the strata above the diamict, two paleomagnetic anomalies occurred. The zone of low VGP latitude values at $14 \mathrm{~m}$ composite depth could be related 
either with the Mono Lake geomagnetic excursion at $33 \mathrm{ka}$ or with the Laschamp excursion at

$41 \mathrm{ka}$ (Roberts 2008). Two ${ }^{14} \mathrm{C}$ ages frame the geomagnetic excursion in the Nesseltalgraben. Two meters above the excursion, an age of 35.5-34.2 cal ka BP was recorded and $6 \mathrm{~m}$ below an age of 49.01-44.6 cal ka BP. Combining these calibrated ${ }^{14} \mathrm{C}$ ages with the magnetostratigraphic results suggests a correlation of the zone of low VGP latitude values with the Laschamp excursion at $41 \mathrm{ka}$. Some uncertainty remains due to consistently higher VGP latitude values of the low-temperature phase compared with AF results during the excursion and higher MAD values in this interval. However, we argue that the lower quality of the AF results during the period of low VGP latitudes (Fig. 7c, f) and the absence of GRM there suggests a weakened palaeofield relatable to an excursion of the palaeomagnetic field. We point out that greigite might record the magnetic signal with some delay (Roberts et al. 2011), however, it has been used for magnetostratigraphic studies in the recent past (Vasiliev et al. 2011). Although the magnetostratigraphic interpretation and the radiocarbon results are in good agreement, a more detailed integrated magnetostratigraphic and rock-magnetic investigation is required to completely rule out a rock-magnetic artefact and to clarify the relationship between the greigite and the higher temperature phase.

To summarize, available evidence strongly suggests that the lower part of the Nesseltalgraben section was deposited during the Early Würmian, covering at least MIS 5c. A hiatus formed between the upper Early and the lower Middle Würmian, which is manifested by the diamict layer. After this erosional unconformity, sedimentation re-started in the Middle Würmian at about 48 to 45 cal. ka BP and lasted at least until 31 cal. ka BP. Likely, sedimentation at the Nesseltalgraben site continued until the LGM, as the lacustrine sequence is overlain by about $8 \mathrm{~m}$ of glaciofluvial deposits and covered by approximately $6 \mathrm{~m}$ of till. A comparison with the stratigraphy of other regional sediment archives reveals that the

389 Nesseltalgraben site represents a time window in the Middle Würmian that is not preserved in other records (Fig. 8). Thus, future investigations of biological and geochemical proxies at 
this site will provide important information about the environmental conditions immediately

prior to the LGM that culminated between about 24 and 17 cal ka BP (Preusser 2004, Wirsig et al. 2016).

\section{Paleoenvironmental implications}

The sedimentological and geochemical data suggest a highly variable paleoenvironment during the Middle Würmian. Almost pure carbonate mud with very little organic matter alternate with organic-rich mud and peaty layers in the lacustrine parts of the sections (Fig. 4). These repeated abrupt facies changes could reflect climatically driven hydrological changes affecting the lake and its catchment. $\delta^{13} \mathrm{C}_{\text {тос }}$ values are frequently used to elucidate the causes of such changes (Lücke and Brauer 2004; Mayr et al. 2009; Zhu et al. 2013), but were rarely applied for pre-LGM records in Central Europe. A notable exception is the Late to Middle Würmian record of Les Echets (France). Similar to our record, a coupling of carbon isotope ratios with TOC and TOC/TN ratios was observed there (Veres et al. 2008). In contrast to the Nesseltalgraben record, however, $\delta^{13} \mathrm{C}_{\mathrm{TOC}}$ and the other geochemical parameters (TOC, TN, TOC/TN) are positively correlated in the Les Echets record. This could point to different types of organic matter than in our record. At Les Echets, intervals with low TOC/TN ratios coupled with low $\delta^{13} \mathrm{C}_{\mathrm{TOC}}$ values were interpreted as cool episodes, 410 including Heinrich events, while high $\mathrm{TOC} / \mathrm{TN}$ ratios and $\delta^{13} \mathrm{C}_{\mathrm{TOC}}$ were related to the 411 relatively warm D-O events (Veres et al. 2008). The current level of radiometric age control is 412 insufficient to examine links between the Nesseltalgraben record and the Greenland ice cores. 13 Nevertheless, it can already be stated that the mechanisms controlling the geochemical 414 signatures were different in the Nesseltalgraben record than at Les Echets, as indicated by the negative correlation between $\delta^{13} \mathrm{C}_{\mathrm{TOC}}$ and the other geochemical values. Strata with low TOC contents are associated with high $\delta^{13} \mathrm{C}_{\mathrm{TOC}}$ and low TOC/TN at our site and very likely reflect 
cool periods. TOC/TN ratios close to or below 10 are typical of these periods and are

commonly regarded as organic matter from algal sources (Meyers 2003). Thus, organic matter in these cooler periods was predominantly authochthonously produced in the lake. TOC/TN ratios well above the threshold of 10 originate in most cases from a mixture of algal sources and organic matter derived from vascular plants such as aquatic macrophytes and terrestrial plants (Meyers 2003; Mayr et al. 2009). Consequently, the vascular plant source at the Nesseltalgraben apparently had a lower $\delta^{13} \mathrm{C}_{\mathrm{TOC}}$ value than the algal organic matter (Fig. 5).

The organic-rich layers are usually interpreted as warmer phases in Würmian records (Veres et al. 2008), which is also shown by palynological studies of sites in Central and Eastern Europe (Boettger et al. 2009). Therefore, we speculate that during warmer phases the increased TOC/TN ratios were caused by higher contributions of terrestrial vascular plant organic matter to the lake sediment. A denser vegetation in the catchment of the lake is a likely explanation for this effect. During cold phases, the catchment was less vegetated and, thus, the organic matter of the lake was mainly restricted to the autochthonous algal source. Although this hypothesis must be substantiated by further investigations, it highlights the potential to identify short-term climatic events, such as D-O events, also at the Nesseltalgraben site by using detailed bulk organic matter geochemistry in combination with high-resolution dating. This will be one of the objectives of future investigations at this site.

Origin, extent and duration of the lake

The repeated existence of the Nesseltalgraben lake in the Early and Middle Würmian raises the question about the origin of the lake and its spatial extent. The sedimentation interruption indicated by the hiatus, the associated diamictic layer and the subsequent sediment onlap points to a complete drainage of the lake after MIS 5c and a re-filling during MIS 3 . As the diamictic unconformity layer obliquely cuts the Early Würmian lacustrine sediments, it is 
unknown whether this drainage occurred during the Early or the Middle Würmian and how much of the previously deposited sediments were eroded. Alternating lake and drainage phases were also reported from other northern Alpine sites. Climate shifts and multiple mass movements affected the geometry and bathymetry of the paleolake at Unterangerberg during the Early and Middle Würmian, but the origin of a major hiatus between 100 and $80 \mathrm{ka}$ BP remains enigmatic (Starnberger et al. 2013). At other sites, temporary lake phases have been related to damming of valleys by alluvial fans, e.g. at Kitzbühel-Lebenberg (Heinisch et al. 2015), or by advancing glaciers such as the Zillertal glacier whose proglacial sediment wedge formed the dam of present-day Lake Achensee high above the Inn valley (Poscher et al. 1994). All mentioned mechanisms of valley damming could potentially have created the lake basin in which the Nesseltalgraben sediments were deposited during the Early and Middle Würmian. However, the small-scale lateral facies changes in the Nesseltalgraben indicate that the lake basin was rather small. Lake deposits of similar facies and age are unknown in the Berchtesgaden valley outside the Nesseltalgraben, although at several sites up to a few meters of carbonate mud were encountered below LGM gravel and till. The local occurrence of the Nesseltalgraben lacustrine deposits points to subrosion as a possible explanation for the development of a local basin occupied by a paleolake. Evaporites of the Permian/Lower Triassic Haselgebirge are present in the subsurface of the Nesseltalgraben and the formation of a large sinkhole appears possible. An extreme example of subrosion in these evaporites was encountered during a drilling campaign in Bad Aussee, where an 800-m-deep depression created by salt dissolution was filled by Quaternary till, gravel and lake sediments (van Husen and Mayr 2007). Sinkholes formed by groundwater subrosion of evaporites, which were filled subsequently by peat and lacustrine sediments, are also known from northern Germany (Stephan 2014) and northern Bavaria (Enters et al. 2008).

\section{Conclusions}


This first study at the Nesseltalgraben demonstrates the high potential of this site for the reconstruction of the Middle and Early Würmian paleoenvironment in the northern Alps. An erosional unconformity separates the Nesseltalgraben sections into a lower and an upper part. Palyno- and magnetostratigraphy suggest an Early Würmian age for the lower and a Middle Würmian age for the upper succession. The latter age assignment is also supported by radiocarbon dates. Bulk geochemical analyses indicate that $\delta^{13} \mathrm{C}_{\mathrm{TOC}}$ values and TOC/TN ratios can be successfully applied to identify climatically controlled changes in the organic matter composition during alternating colder and warmer episodes. Future investigations should aim on a higher temporal resolution of radiogenic and biostratigraphic dates associated with high-resolution analyses of bioproxies and geochemical parameters. Such studies have the potential for a direct comparison with the well-dated Greenland ice core records (Rasmussen et al. 2014) and Alpine speleothems (Moseley et al. 2014). To evaluate the strong and rapid temperature variations during the Last Glacial in the Alps, known as D-O events from Greenland, more qualitative and quantitative climate reconstructions are needed. The Nesseltalgraben site provides an excellent inner-Alpine archive that could contribute to address this objective.

We are much indebted to Josef März (Berchtesgaden) for generously supporting the fieldwork and analyses. He discovered the Nesseltalgraben site and was one of the driving forces for 491 initiating this study. The palynological studies were partly financed by the Bavarian 492 Environment Agency (Bayerisches Landesamt für Umwelt) in the framework of the EU493 funded project "Informationsoffensive Oberflächennahe Geothermie". We acknowledge research funding by the Deutsche Forschungsgemeinschaft (DFG) (MA 4235/10-1). 


\section{References}

Antoine P, Rousseau DD, Moine O, Kunesch S, Hatté C, Land A, Tissoux H, Zöller L (2009) Rapid and cyclic aeolian deposition during the Last Glacial in European loess: a highresolution record from Nussloch, Germany. Quat Sci Rev 28: 2955-2973

Barrett S, Drescher-Schneider R, Starnberger R, Spötl C (2016) Insights into MIS 3 and 4 climate in the Alps from the Baumkirchen paleo-lake site: Results of pollen analysis. Geophys Res Abstracts 18, EGU2016-6712-1.

Bayerisches Landesamt für Umwelt (2013) Gefahrenhinweiskarte Alpen mit Alpenvorland, $\begin{array}{ll}\text { Landkreis } & \text { Berchtesgadener Land }\end{array}$ (http://www.lfu.bayern.de/geologie/massenbewegungen/gefahrenhinweiskarten/doc/beri cht_gefahrenhinweiskarte_lkr_bgl.pdf). Augsburg, Germany.

Beug H-J (2004) Leitfaden der Pollenbestimmung für Mitteleuropa und angrenzende Gebiete. Pfeil, Munich, Germany

Boch R, Cheng H, Spötl C, Edwards RL, Wang X, Häuselmann P (2011) NALPS: a precisely dated European climate record 120-60 ka. Clim Past 7: 1247-1259

Boettger T, Novenko EY, Velichko AA, Borisova OK, Kremenetski KV, Knetsch S, Junge FW (2009) Instability of climate and vegetation dynamics in Central and Eastern Europe during the final stage of the Last Interglacial (Eemian, Mikulino) and Early Glaciation. Quat Int 207: 137-144

Briant RM, Bateman MD (2009) Luminescence dating indicates radiocarbon underestimation in late Pleistocene fluvial deposits from eastern England. J Quat Sci 24: 916-927 
518 de Vries H, Barendsen GW (1952) A new technique for the measurement of age by radiocarbon. Physica 18: 652

Drescher-Schneider R (2000) Die Vegetations- und Klimaentwicklung im Riß-/WürmInterglazial und im Früh- und Mittelwürm in der Umgebung von Mondsee. Ergebnisse der pollenanalytischen Untersuchungen. In: van Husen D (ed): Klimaentwicklung im Riß/Würm-Interglazial (Eem) und Frühwürm (Sauerstoffisotopenstufe 6-3) in den Ostalpen. Mitt Komm Quartärforschung 12: 39-92

Enters D, Dörfler W, Zolitschka B (2008) Historical soil erosion and land-use change during the last two millennia recorded in lake sediments of Frickenhauser See, northern Bavaria, central Germany. The Holocene 18: 243-254

Faegri K, Iversen J (1989) Textbook of Pollen Analysis. John Wiley \& Sons Ltd., Chichester, United Kingdom

Fiebig M, Herbst P, Drescher-Schneider R, Lüthgens C, Lomax J, Doppler G (2014) Some remarks about a new Last Glacial record from the western Salzach foreland glacier basin (Southern Germany). Quat Int 328-329: 107-119

Filzer P (1967) Das Interglazial Riß-Würm vom Pfefferbichl bei Buching im Allgäu. Vorzeit 16: $9-24$

Genty D, Blamart D, Ouahdi R, Gilmour M, Baker A, Jouzel J, Van-Exter S (2003) Precise dating of Dansgaard-Oeschger climate oscillations in western Europe from stalagmite data. Nature 421: 833-837

Grootes PM (1977): Thermal diffusion isotopic enrichment and radiocarbon dating beyond 50000 years BP. Proefschrift Rijksuniversiteit te Groningen, Groningen, Netherlands 
Grüger E (1979a) Spätriß, Riß/Würm und Frühwürm am Samerberg in Oberbayern - ein vegetationsgeschichtlicher Beitrag zur Gliederung des Jungpleistozäns. Geologica Bavarica 80: 5-64

Grüger E (1979b) Die Seeablagerungen vom Samerberg/Obb. und ihre Stellung und ihre Stellung im Jungpleistozän. Eiszeitalter u. Gegenwart 29: 23-34

Grüger E, Schreiner A (1993) Riß/Würm- und würmzeitliche Ablagerungen im Wurzacher Becken (Rheingletschergebiet). N Jb Geol Paläont Abh 189: 81-117

Heinisch H, Pestal G, Reitner J (2015) Erläuterungen zu Blatt 122 Kitzbühel. Geologische Bundesanstalt, Vienna, Austria

Heiri O, Koinig K, Spötl C, Barrett S, Brauer A, Drescher-Schneider R, Gaar D, Ivy-Ochs S, Kerschner H, Luetscher M, Moran A, Nicolussi K, Preusser F, Schmidt R, Schoeneich P, Schwörer C, Sprafke T, Terhorst B, Tinner W (2014) Palaeoclimate records 60-8 ka in the Austrian and Swiss Alps and their forelands. Quat Sci Rev 106: 186-205

Kirschvink J (1980) The least squares lines and plane analysis of palaeomagnetic data. Geophys J R Astr Soc 62: 699-718.

Kühnel J (1929) Geologie des Berchtesgadener Salzberges. N Jb Min Geol Paläontol Beil-Bd 59: $357-430$

Lai ZP, Mischke S, Madsen D (2014) Paleoenvironmental implications of new OSL dates on the formation of the "Shell Bar" in the Qaidam Basin, northeastern Qinghai-Tibetan Plateau. J Paleolimnol 51: 197-210

Lisiecki LE, Raymo ME (2009) Diachronous benthic $\delta^{18} \mathrm{O}$ responses during late Pleistocene terminations. Palaeoceanography 24: PA3210, doi:10.1029/2009PA001732 
562 Lücke A, Brauer A (2004) Biogeochemical and micro-facial fingerprints of ecosystem

response to rapid Late Glacial climatic changes in varved sediments of Meerfelder Maar (Germany). Palaeogeogr Palaeoclimatol Palaeoecol 211: 139-155

Mayr C, Lücke A, Maidana NI, Wille M, Haberzettl T, Corbella H, Ohlendorf C, Schäbitz F, Fey M, Janssen S, Zolitschka B (2009) Isotopic fingerprints on lacustrine organic matter from Laguna Potrok Aike (southern Patagonia, Argentina) reflect environmental changes during the last 16,000 years. J Paleolimnol 42: 81-102.

Meyers PA (2003) Applications of organic geochemistry to paleolimnological reconstructions: a summary of examples from the Laurentian Great Lakes. Org Geochem 34: 261-289

Moseley GE, Spötl C, Svensson A, Cheng H, Brandstätter S, Lawrence Edwards R (2014) Multi-speleothem record reveals tightly coupled climate between central Europe and Greenland during marine Isotope Stage 3. Geology 42: 1043-1046

Müller U, Pross J, Bibus E (2003) Vegetation response to rapid climate change in Central Europe during the past 140,000 yr based on evidence from the Füramoos pollen record. Quat Res 59: 235-245

Penck A (1882) Die Vergletscherung der deutschen Alpen - Ihre Ursachen, periodische Wiederkehr und ihr Einfluss auf die Bodengestaltung. Leipzig.

Peschke P (1983) Palynologische Untersuchungen interstadialer Schieferkohlen aus dem schwäbisch-oberbayerischen Alpenvorland. Geologica Bavarica 84: 69-99

Pichler H (1963) Geologische Untersuchungen im Gebiet zwischen Roßfeld und Markt Schellenberg im Berchtesgadener Land. Beih Geol Jb 44: 129-203 
Pini R, Ravazzi C, Reimer PJ (2010) The vegetation and climate history of the last glacial cycle in a new pollen record from Lake Fimon (southern Alpine foreland, N-Italy). Quat Sci Rev 29: 3115-3137

Poscher G (1994) Fazies und Genese der pleistozänen Terrassensedimente im Tiroler Inntal und seinen Seitentälern- Teil 1: Der Achenseedamm. Jb Geol Bundesanstalt 137: 171186

Preusser F (2004) Towards a chronology of the Late Pleistocene in the northern Alpine Foreland. Boreas 33: 195-210

Rasmussen, S.O., Bigler, M., Blockley, S., Blunier, T., Buchardt, B., Clausen, H., Cvijanovic, I., Dahl-Jensen, D., Johnsen, S., Fischer, H., Gkinis, V., Guillevic, M., Hoek, W., Lowe, J., Pedro, J., Popp, T., Seierstad, I., Steffensen, J., Svensson, A., Vallelonga, P., Vinther, B., Walker, M., Wheatley, J.J., Winstrup, M. (2014) A stratigraphic framework for abrupt climatic changes during the Last Glacial period based on three synchronized Greenland ice-core records: refining and extending the INTIMATE event stratigraphy. Quat Sci Rev 106: 14-28.

Reille M (1998) Pollen et Spores d'Europe et d'Afrique du Nord. Supplement 2. Laboratoire de Botanique historique et Palynologie, Marseille, France

Reimer PJ, Bard E, Bayliss A, Beck JW, Blackwell PG, Bronk Ramsey C, Buck CE, Cheng H, Edwards RL, Friedrich M, Grootes PM, Guilderson TP, Haflidason H, Hajdas I, Hatté C, Heaton TJ, Hoffmann DL, Hogg AG, Hughen KA, Kaiser KF, Kromer B, Manning SW, Niu M, Reimer RW, Richards DA, Scott EM, Southon JR, Staff RA, Turney CSM, van der Plicht J (2013) IntCal13 and MARINE13 radiocarbon age calibration curves 0-50,000 years cal BP. Radiocarbon 55: 1869-1887 
Reitner JM (2011) Das Inngletschersystem während des Würm-Glazial. In: Gruber A (ed)

Arbeitstagung der Geologischen Bundesanstalt Blatt 88 Achenkirch. Conference proceedings: $79-88$.

Reitner J, Draxler I (2004) Inner alpine valley fills as archives of climatic and depositional conditions during MIS 5 (Eastern Alps/Tyrol/Austria). Poster, 32nd IGC, Florence, Italy; accessible at https://www.geologie.ac.at/fileadmin/user_upload/dokumente/pdf/ poster/Poster_IGC_2004r.pdf

Roberts AP (2008) Geomagnetic excursions: Knowns and unknowns. Geophys Res Lett 35: L17307, doi :10.1029/2008GL03471

Roberts AP, Chang L, Rowan CJ, Horng CS, Florindo F (2011) Magnetic properties of sedimentary greigite $\left(\mathrm{Fe}_{3} \mathrm{~S}_{4}\right)$ : An update. Rev Geophys 49: RG1002.

Seierstad IK, Abbott PM, Bigler M, Blunier T, Bourne AJ, Brook E, Buchardt SL, Buizert C, Clausen HB, Cook E, Dahl-Jensen D, Davies SM, Guillevic M, Johnsen SJ, Pedersen DS, Popp TJ, Rasmussen SO, Severinghaus JP, Svensson A, Vinther BM (2014) Consistently dated records from the Greenland GRIP, GISP2 and NGRIP ice cores for the past $104 \mathrm{ka}$ reveal regional millennial-scale $\delta^{18} \mathrm{O}$ gradients with possible Heinrich event imprint. Quat Sci Rev 106: 29-46

Sirocko F, Seelos K, Schaber K, Rein B, Dreher F, Diehl M, Lehne R, Jäger K, Krbetschek M, Degering D (2005) A late Eemian aridity pulse in central Europe during the last glacial inception. Nature 436: 833-836

Sponagel H, Grottenthaler W, Hartmann K-J, Hartwich R, Janetzko P, Joisten H, Kühn D, Sabel K-J, Traidl R (2005) Bodenkundliche Kartieranleitung. Schweizerbart, Stuttgart, Germany.

Spötl C (1989) The Alpine Haselgebirge Formation, Northern Calcareous Alps (Austria): Permo-Scythian evaporites in an alpine thrust system. Sed Geol 65: 113-125 
Starnberger R, Drescher-Schneider R, Reitner J, Rodnight H, Reimer P, Spötl C (2013) Late Pleistocene climate change and landscape dynamics in the Eastern Alps: the inneralpine Unterangerberg record (Austria). Quat Sci Rev 68: 17-42

Stephan H-J (2014) Climato-stratigraphic subdivision of the Pleistocene in SchleswigHolstein, Germany and adjoining areas. E\&G Quat Sci J 63: 3-18

Stephenson A, Snowball IF (2001) A large gyromagnetic effect in greigite. Geophys J Int 145: $570-575$

Stockmarr J (1971) Tablets with spores used in absolute pollen analysis. Pollen et Spores 13: $615-621$

Stuiver M, Polach HA (1977) Reporting of C-14 data - Discussion. Radiocarbon 19: 355-363

Van Husen D (1999) Geological processes during the Quaternary. Mitt Österr Geol Ges 92: $135-156$

Van Husen D, Mayr M (2007) The hole of Bad Aussee. An unexpected overdeepened area in NW Steiermark, Austria. Austrian J Earth Sci 100: 128-136

Vasiliev I, Iosifidi AG, Khramov AN, Krijgsman W, Kuiper K, Langereis CG, Popov VV, Stoica M, Tomsha VA, Yudin SV (2011) Magnetostratigraphic and radio-isotope dating of upper Miocene-lower Pliocene sedimentary successions of the Black Sea Basin (Taman Peninsula, Russia). Palaeogeogr Palaeoclimatol Palaeoecol 310: 168-175

Veres D, Lallier-Vergès E, Wohlfarth B, Lacourse T, Kéravis D, Björck S, Preusser F, Andrieu-Ponel V, Ampel L (2008) Climate-driven changes in lake conditions during late MIS 3 and MIS 2: a high-resolution geochemical record from Les Echets, France. Boreas 38: 230-243

Wack M, Gilder S (2012) The SushiBar: An automated system for palaeomagnetic investigations. Geochem Geophys Geosyst 13: 1-24 
Welten M (1981) Verdrängung und Vernichtung der anspruchsvollen Gehölze am Beginn der letzten Eiszeit und die Korrelation der Frühwürm-Interstadiale in Mittel- und Nordeuropa. Eiszeitalter und Gegenwart 31: 187-202

Wirsig C, Zasadni J, Christl M, Akçar N, Ivy-Ochs S (2016) Dating the onset of LGM ice surface lowering in the High Alps. Quat Sci Rev 143: 37-50

Wohlfarth B, Veres D, Ampel L, Lacourse T, Blaauw M, Preusser F, Andrieu-Ponel V, Kéravis D, Lallier-Vergès E, Björck S, Davies SM, Beaulieu J-L de, Risberg J, Hormes A, Kasper HU, Possnert G, Reille M, Thouveny N, Zander A (2008) Rapid ecosystem response to abrupt climate changes during the last glacial period in western Europe, 4016 ka. Geology 36: 407-410

Zhu J, Lücke A, Wissel H, Müller D, Mayr C, Ohlendorf C, Zolitschka B, PASADO Science Team (2013) The last Glacial-Interglacial transition in Patagonia, Argentina: the stable isotope record of bulk sedimentary organic matter from Laguna Potrok Aike. Quat Sci $\operatorname{Rev} 71: 205-218$

Zijderveld J (1967) A. C. demagnetization of rocks: Analysis of results. In: Collinson DW, Creer KM, Runcorn SK (eds.) Methods in Palaeomagnetism. Elsevier, Amsterdam, pp 254-286 

694

Figure captions

Fig. 1. Peat and lacustrine sites of Würmian age in southeastern Germany and northern Austria that are discussed in the text. The Nesseltalgraben is located close to the city of Salzburg. The maximal extents of piedmont glaciers during the last (Würmian) and penultimate (Rissian) glaciations are also shown.

Fig. 2. Simplified geological sketch of the study area based on Kühnel (1929) and Pichler (1963). Quaternary cover (moraine, fluvial deposits and talus mainly of post-LGM age) has been removed.

Fig. 3. Stratigraphy, lithology and uncalibrated radiocarbon ages of the five sections exposed in the Nesseltalgraben. Abbreviations for grain size classes determined with field methods: clay $(\mathrm{T})$, silty clay $(\mathrm{Tu})$, clayey silt $(\mathrm{Ut})$, silt $(\mathrm{U})$, sandy silt (Us), silty sand (Su), fine sand (fS), medium sand (mS), sandy gravel (Gs), fine gravel (fG), coarse gravel (gG), diamict (X), peaty clay or compressed peat $(\mathrm{Hp})$. The segments in which samples for palynological and magnetostratigraphic investigations were taken are indicated by vertical bars.

691 Fig. 4. Composite profile compiled from three adjacent sections (B, C, D) exposed in the 692 Nesseltalgraben showing facies variations and geochemical data. The composite depth is 693 given in meters below gravel layers that form the base of glaciofluvial and till deposits of about $14 \mathrm{~m}$ thickness. Arrows mark the position of uncalibrated radiocarbon ages. The composite profile comprises an approximately 24 m-long predominantly Middle Würmian lacustrine sediment sequence. Legend as in Fig. 3.

698 Fig. 5. Correlations between $\delta^{13} \mathrm{C}_{\mathrm{TOC}}$ values versus $\mathrm{TOC} / \mathrm{TN}, \quad \delta^{13} \mathrm{C}_{\mathrm{TOC}}$ values versus 
logarithmized TN and TOC, respectively, and between TOC versus TN.

Fig. 6. Pollen diagram of the lower part of section D, directly below and above the diamict, plotted on the composite depth scale of Fig. 4. The amounts of arboreal pollen (AP, black area), shrubs (gray), and non-arboreal (NAP, white) are indicated to the left of the individual taxa.

Fig. 7. Magnetostratigraphic results of two intervals of the Nesseltal section. (a+b). Plot of VGP latitude, intensity of NRM and median angular deviation (MAD) value versus composite depth of selected samples from the Nesseltalgraben section. Squares (circles) represent results based on AF (thermal) treatment. (c-i) orthogonal vector endpoint diagrams (Zijderveld 1967) of representative samples from the Nesseltalgraben section (c-f) together with according decay plot (h) and stereographic projection (g). Open (closed) symbols indicate projections onto the vertical (horizontal) plane. Stratigraphic height of samples is shown below the graphs (in $\mathrm{cm}$ ). Value indicates amount of each plotted marked intervals (e.g. 10-6) in $\mathrm{Am}^{2}$. (i) shows sample mean directions in a stereographic projection. HT samples represent unused high temperature component samples. Selected steps in $\mathrm{mT}$ and ${ }^{\circ} \mathrm{C}$ are indicated.

Fig. 8. Schematic overview of the temporal development of ice extent (gray area) and stratigraphic range of important and well-dated Würmian lacustrine palaeoclimatic archives (vertical bars) in the northeastern Alps and their foreland (modified from Reitner (2011) and van Husen (2000), stratigraphic ranges of Füramoos, Baumkirchen and Unterangerberg are from Müller et al. (2003), Barrett et al. (2016) and Starnberger et al. (2013), respectively). The stacked northern Atlantic $\delta^{18} \mathrm{O}$ record from benthic foraminifera and the marine isotope stages (MIS) are shown for comparison (Lisiecki and Raymo 2009). 


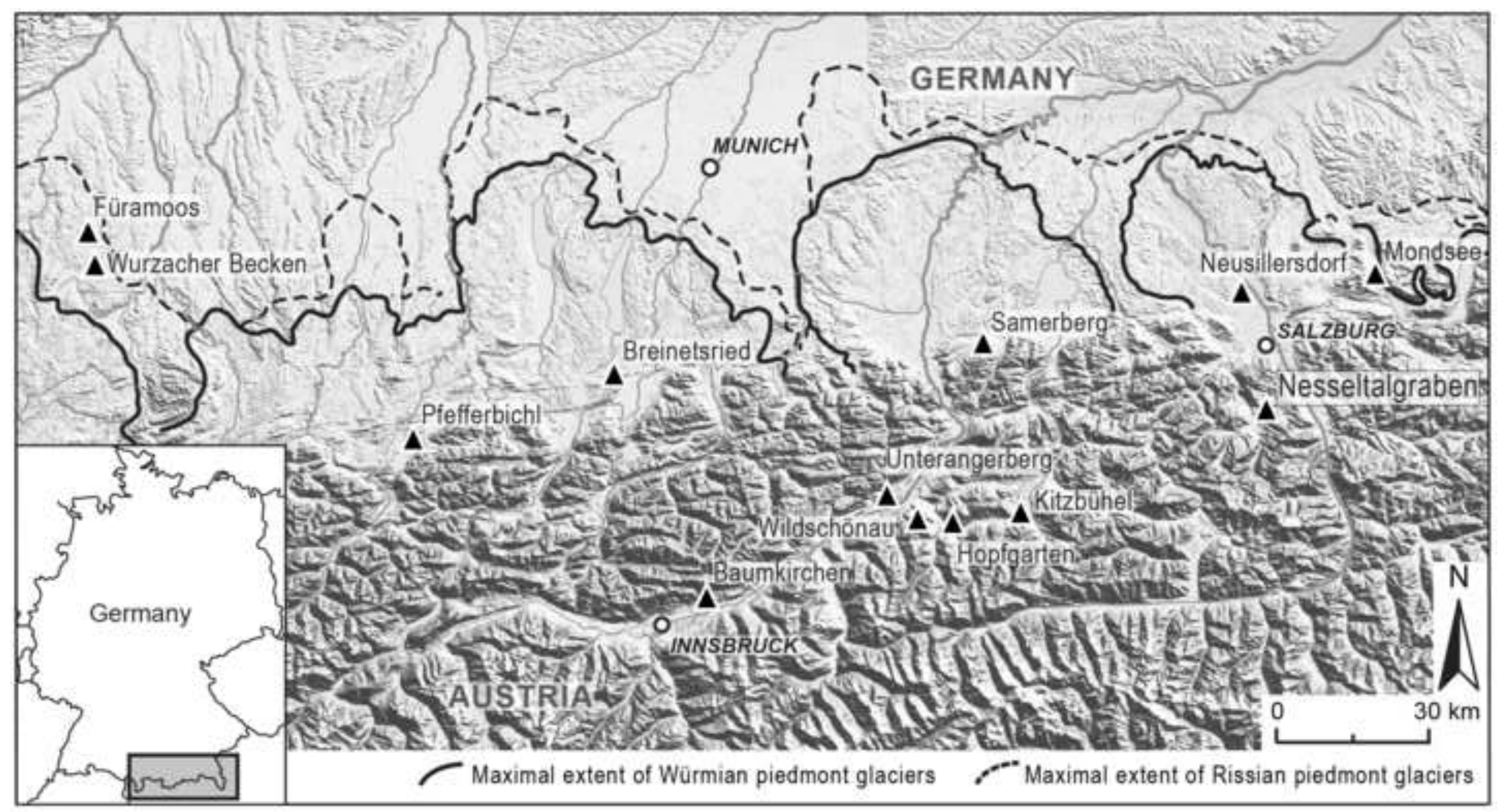




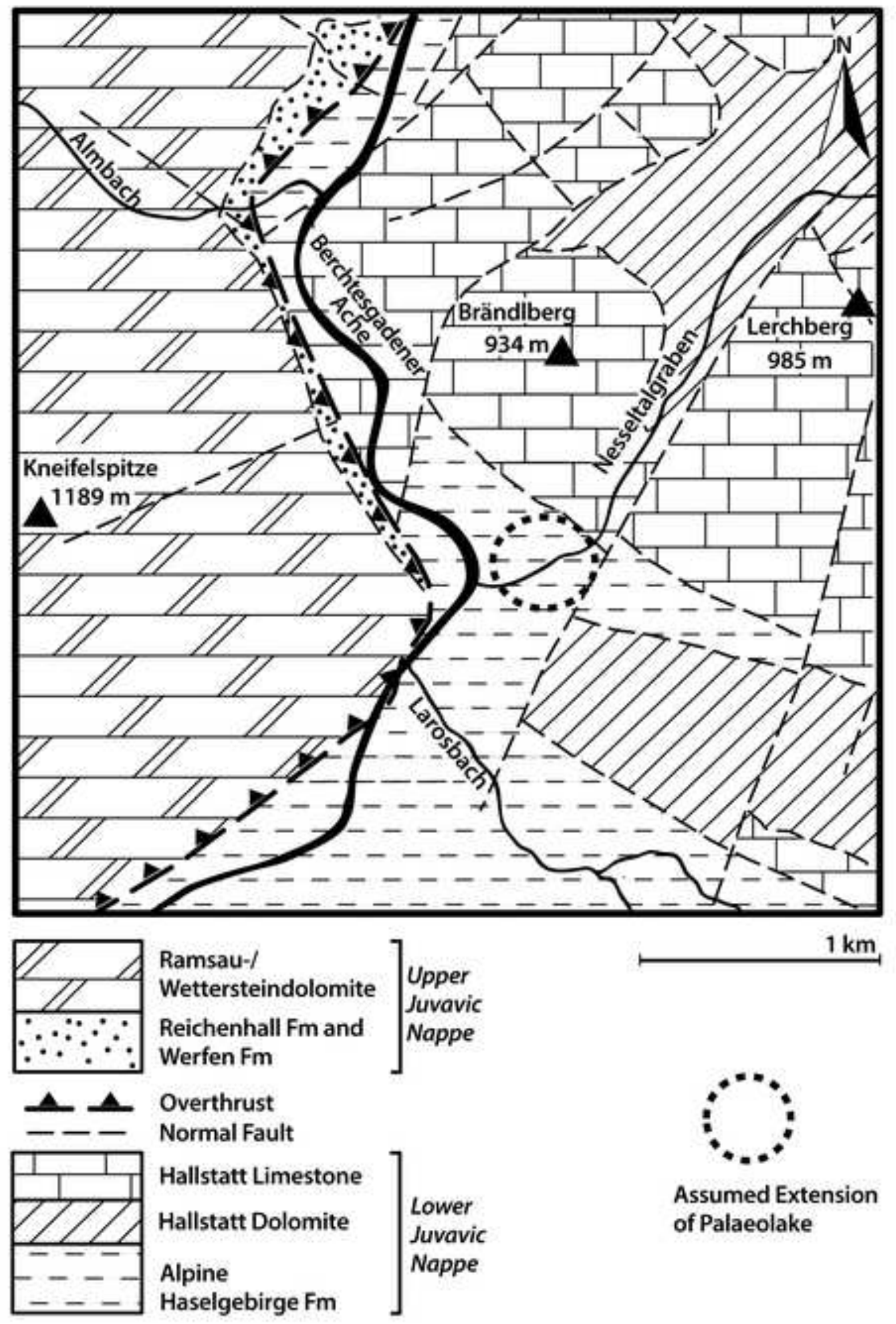


Click here to download Figure Fig.3-Small.pdf $\underline{\underline{\underline{ }}}$

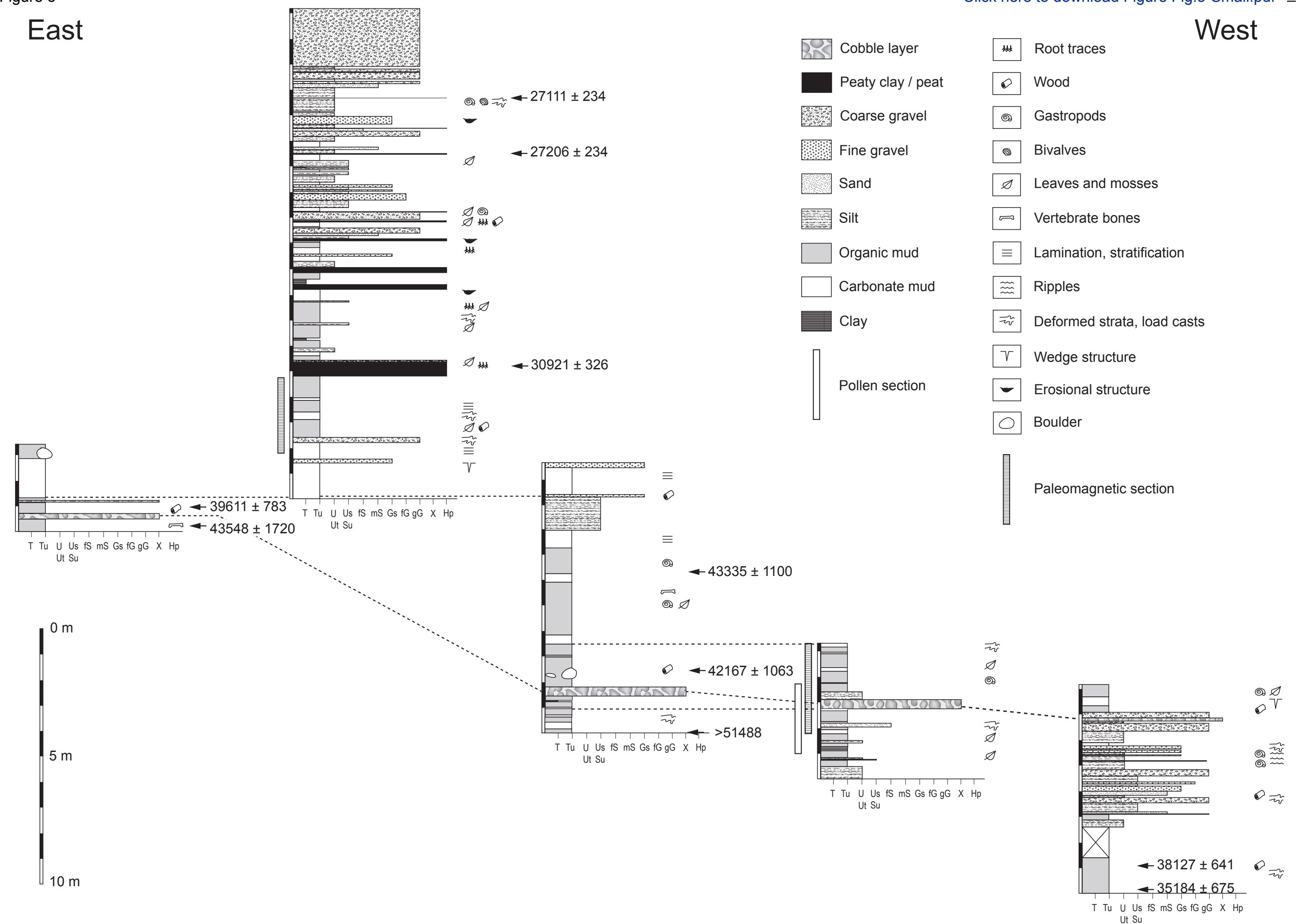

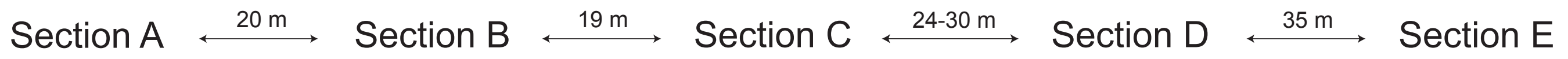




\section{Composite} depth

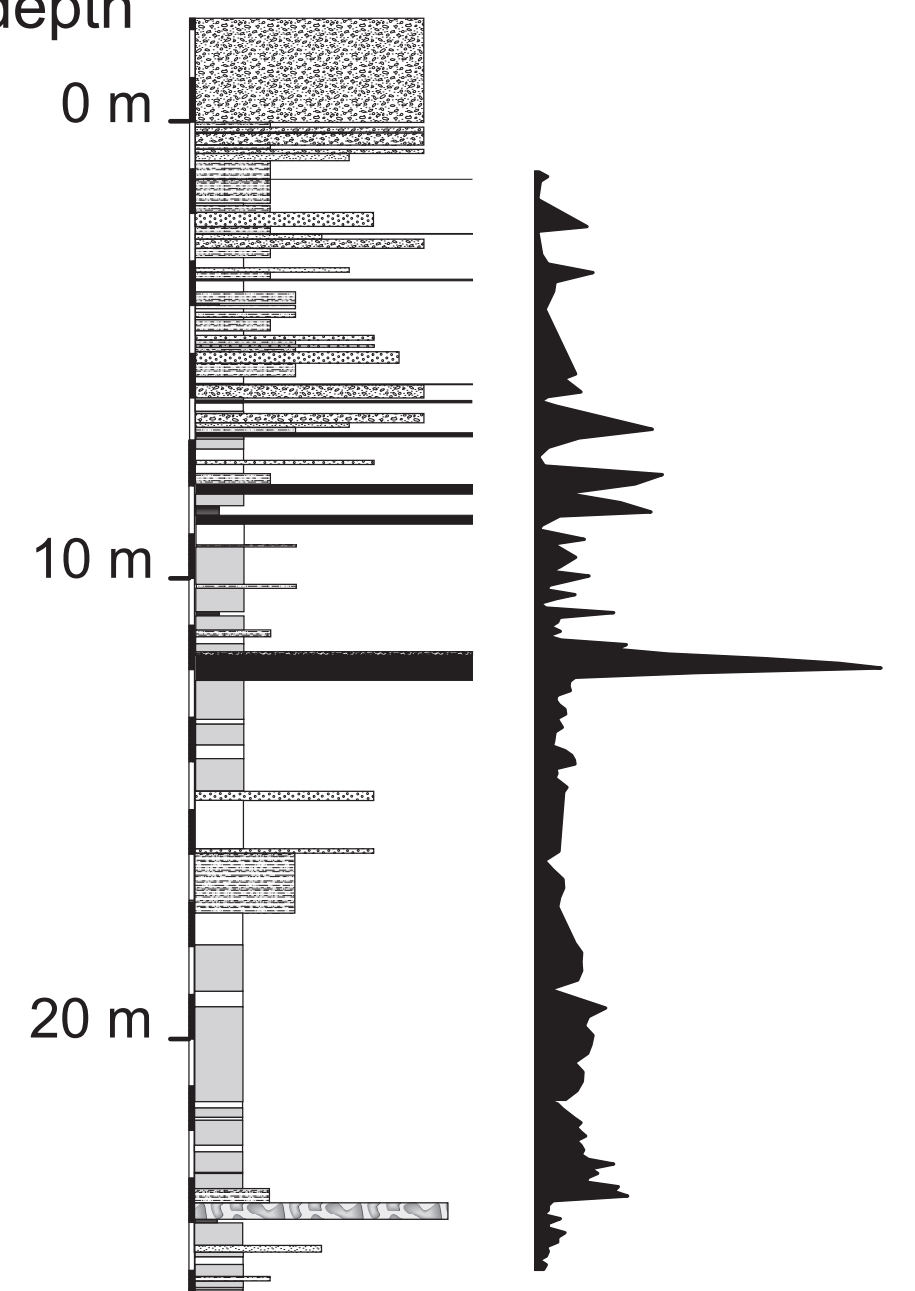

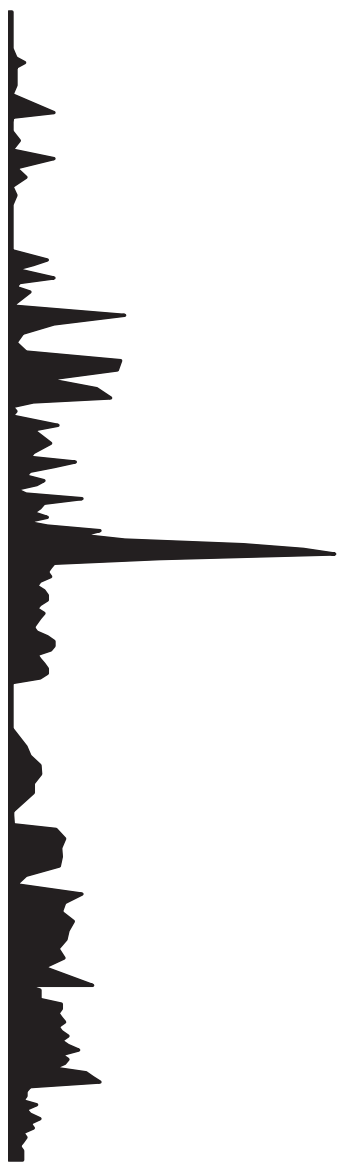
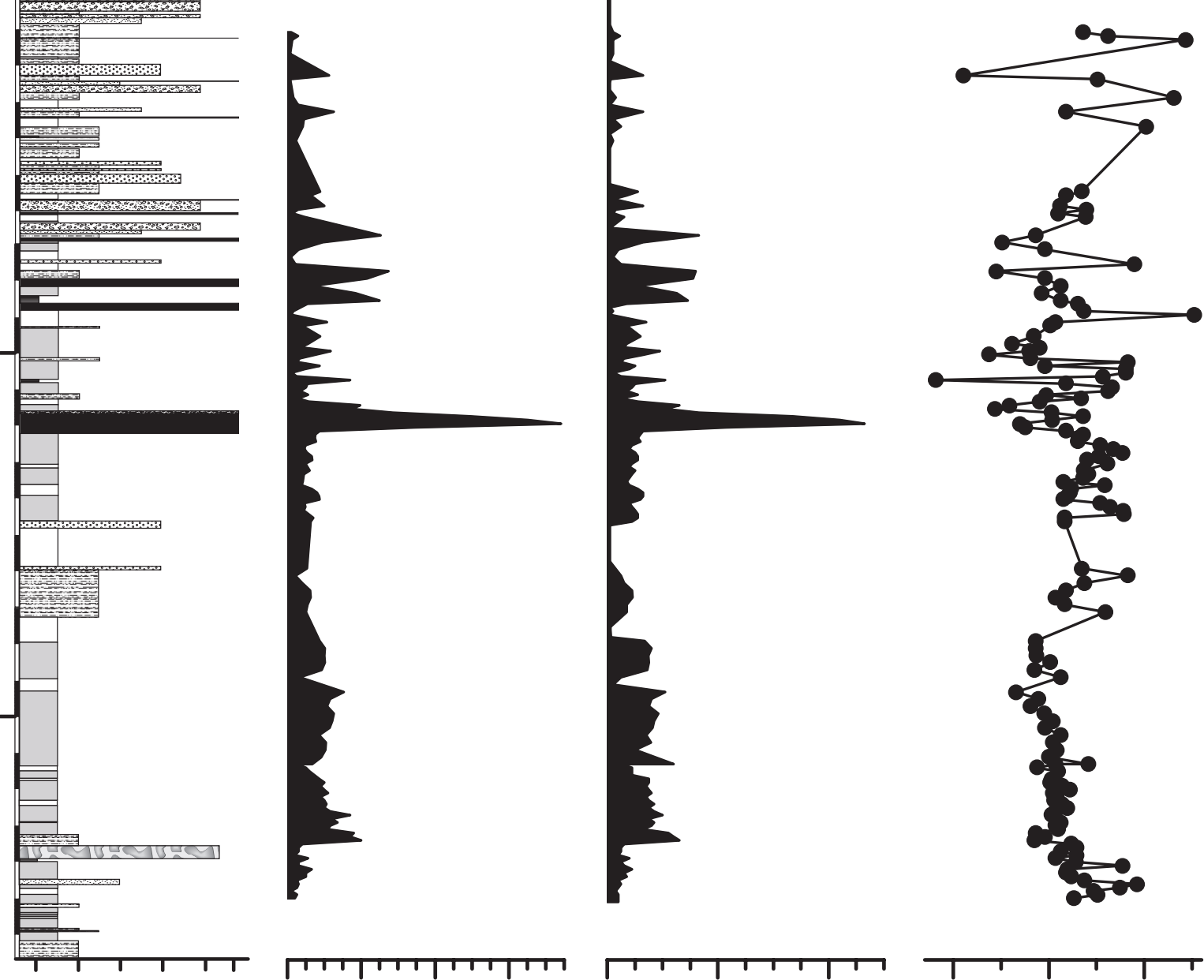

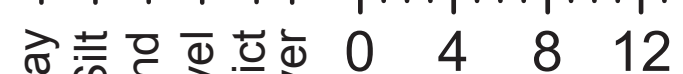

U ल

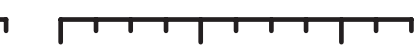

$\begin{array}{lll}0.0 & 0.4 & 0.8\end{array}$

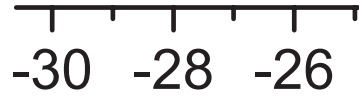

TOC (\%)

TN (\%)

$\delta^{13} \mathrm{C}_{\text {TOC }}(\%)$

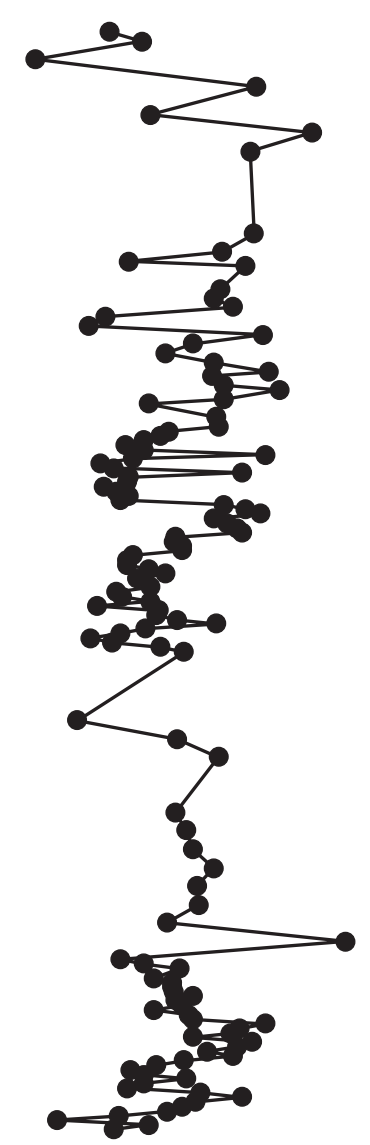

$-43335 \pm 1100$

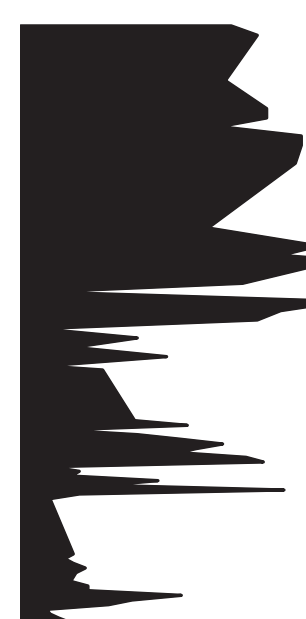

$-27111 \pm 234$

$-27206 \pm 234$

$-30921 \pm 326$
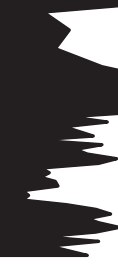

$-42167 \pm 1063$

${ }^{14} \mathrm{C}$ dates

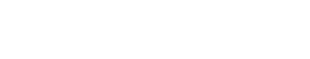

$\begin{array}{lllll}10 & 20 & 0 & 4 & 8\end{array}$

TOC/TN TIC (\%) 


\section{Figure 5}
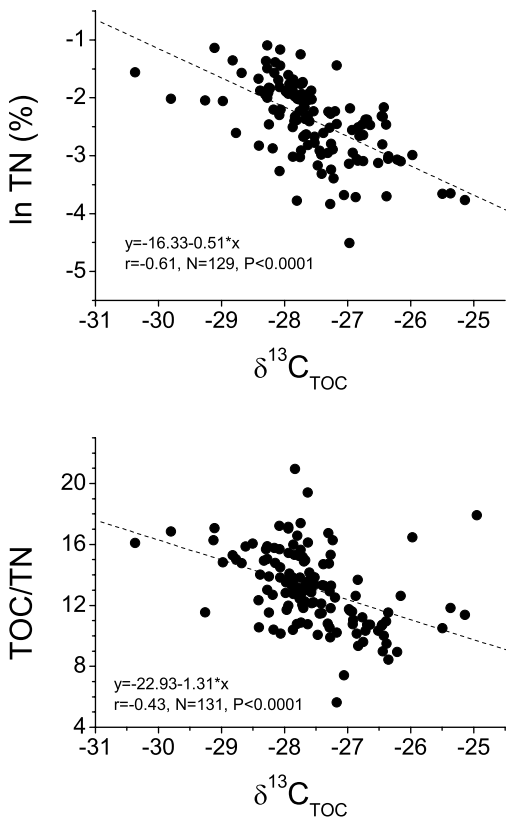

Click here to download Figure Fig.5.p.lf
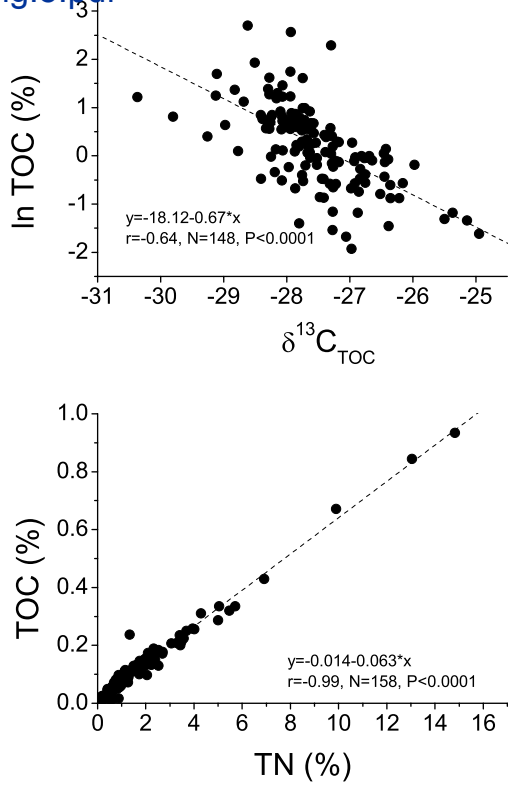


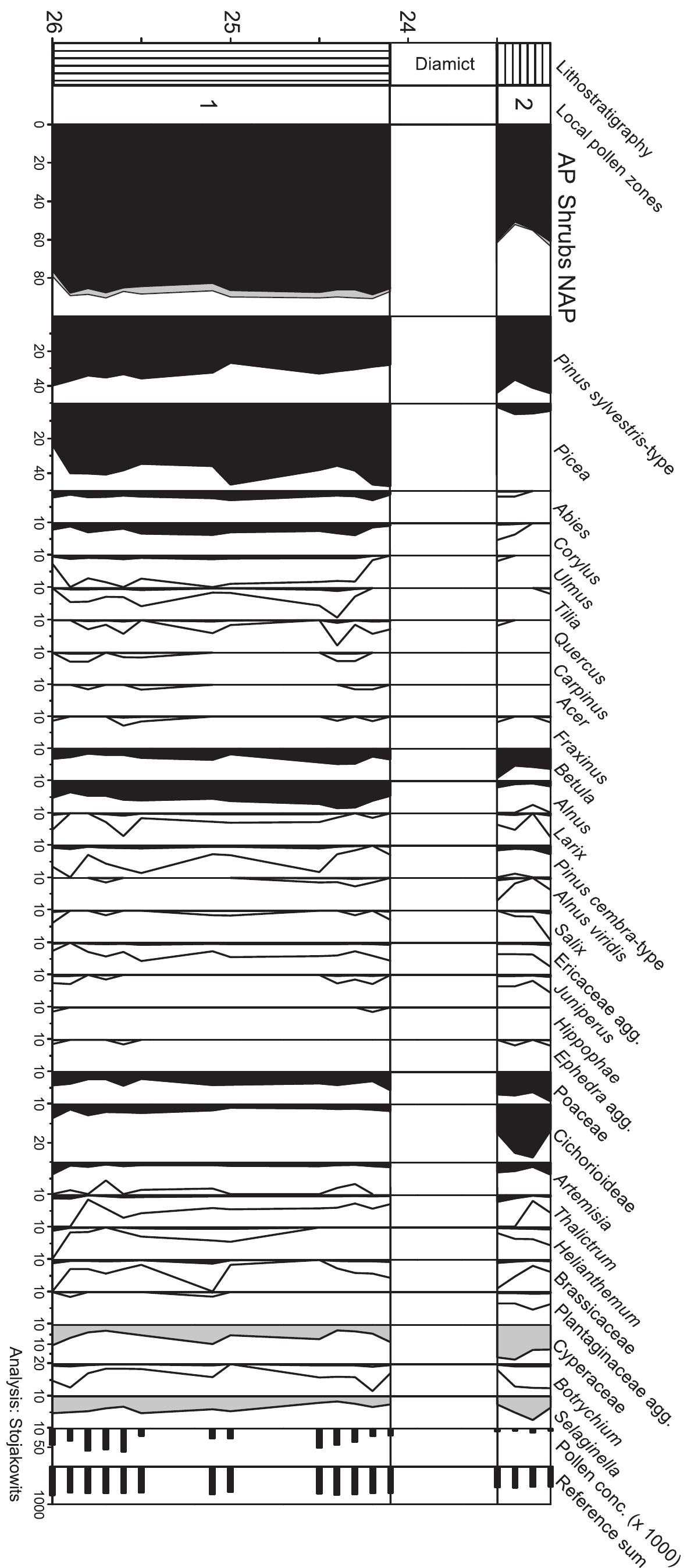




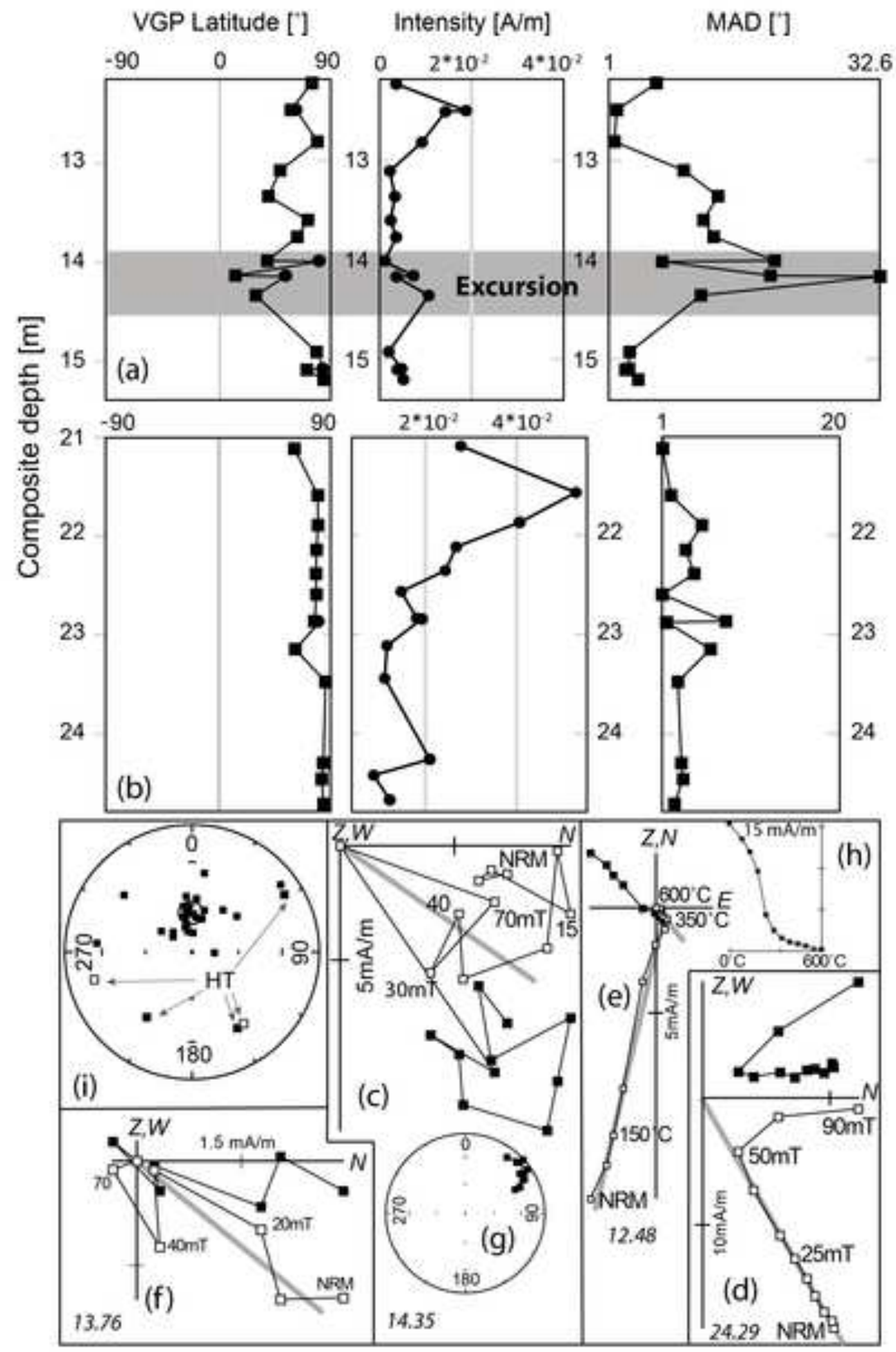




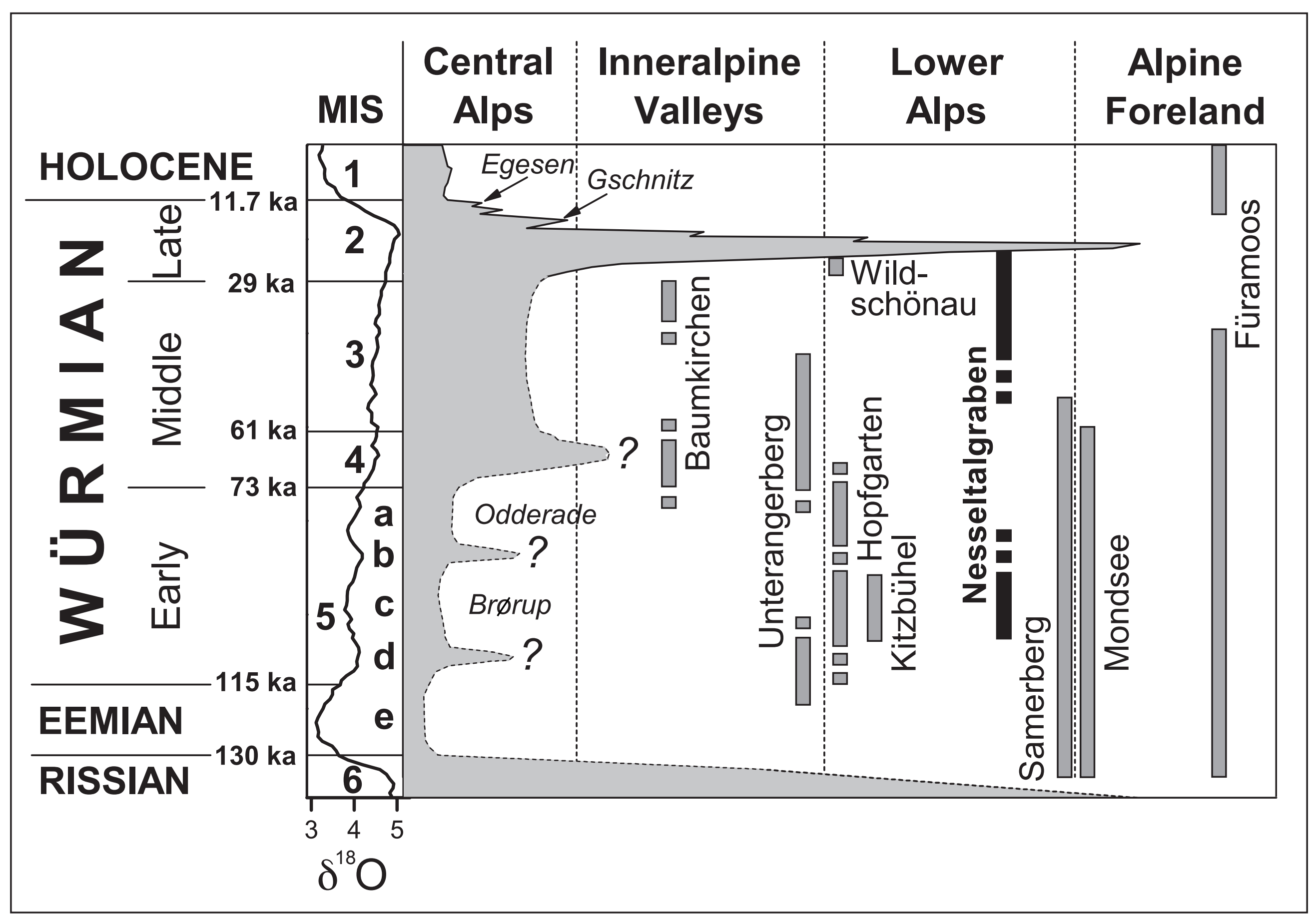


Table 1. Radiocarbon ages obtained from the Nesseltalgraben sections

\begin{tabular}{|c|c|c|c|c|c|c|}
\hline $\begin{array}{l}\text { Internal } \\
\text { No. }\end{array}$ & Lab Code & Material & $\begin{array}{l}\text { Uncalibrated } \\
\text { radiocarbon } \\
\text { date }(\mathrm{BP})\end{array}$ & $\begin{array}{l}\text { Analytical } \\
\text { error }\end{array}$ & $\begin{array}{l}\text { Calibrated age } \\
(\text { cal BP, } 2 \sigma)\end{array}$ & Section \\
\hline NE-13 & UBA-27629 & twig & 43,548 & $\pm 1,720$ & $\begin{array}{c}>50,000- \\
44,266\end{array}$ & A \\
\hline NE-4 & UBA-24902 & twig & 39,611 & \pm 783 & $44,689-42,248$ & $\mathrm{~A}$ \\
\hline NE-7 & UBA-24910 & $\begin{array}{l}\text { twig from } \\
\text { peaty layer }\end{array}$ & 27,111 & \pm 234 & $31,393-30,816$ & B \\
\hline NE-6 & UBA-24911 & $\begin{array}{l}\text { compressed } \\
\text { peat }\end{array}$ & 27,206 & \pm 234 & $31,452-30,864$ & B \\
\hline NE-1 & Erl-17397 & $\begin{array}{l}\text { compressed } \\
\text { peat }\end{array}$ & 30,921 & \pm 326 & $35,520-34,203$ & B \\
\hline NE-5 & UBA-24903 & $\begin{array}{l}40 \mathrm{~cm} \text { long } \\
\text { piece of } \\
\text { wood }\end{array}$ & 43,335 & $\pm 1,100$ & $49,051-44,634$ & $\mathrm{C}$ \\
\hline NE-2 & Erl-17398 & $\begin{array}{l}\text { piece of } \\
\text { wood }\end{array}$ & 42,167 & $\pm 1,063$ & $47,635-43,514$ & $\mathrm{C}$ \\
\hline NE-10 & UBA-27628 & $\begin{array}{l}\text { moss } \\
\text { remains }\end{array}$ & $>51,488$ & & & $\mathrm{C}$ \\
\hline NE-3 & UBA-24901 & $\begin{array}{l}\text { piece of } \\
\text { wood }\end{array}$ & 38,127 & \pm 641 & $43,180-41,384$ & $\mathrm{E}$ \\
\hline NE-8 & UBA-27627 & $\begin{array}{l}\text { piece of } \\
\text { bark }\end{array}$ & 35,184 & \pm 675 & $41,232-38,401$ & $\mathrm{E}$ \\
\hline
\end{tabular}

